\title{
Minyak Atsiri sebagai Bahan Aktif Konservasi Benda Cagar Budaya
}

\author{
Riyanto \\ Prodi Kimia Fakultas MIPA Universitas Islam Indonesia \\ Email: riyanto@uii.ac.id
}

\begin{abstract}
Abstrak: Konservasi dengan mencegah kerusakan benda cagar budaya akibat tumbuhnya bakteri, lumut, jamur, dan mikroorganisme sangat perlu untuk dilakukan. Konservasi BCB selama ini menggunakan bahan kimia berbahaya seperti 5-bromo-3-sec-butyl-6-methyluracil (Hyvar-X), xylophene, aldrin, malathion, parathion, DDT (Dichloro Diphenyl Trichloroethane) dan CCA (Chromated Copper Arsenat). Bahan kimia berbahaya tersebut dapat dilakukan penggantian dengan menggunakan bahan alam yang berupa minyak atsiri, yang diambil dari tanaman sereh wangi, cengkeh, pala, jahe karena mengandung zat-zat aktif seperti sitronelal, sitronelol, geraniol, eugenol, cineol, dan camphene yang dapat membasmi, membunuh, dan mengusir serangga, bakteri, dan jamur. Penggunaan minyak atsiri sebagai bahan konservasi BCB aman terhadap lingkungan, manusia, dan mampu mencegah kerusakan BCB.
\end{abstract}

\section{Kata Kunci: Minyak atsiri, Zat aktif, Bahan Konservasi}

\begin{abstract}
Abstrak: Conservation for controlling damages from the growth of bacteria, moss, fungi, and microorganism is needed to be conducted in a cultural heritage. So far the conservation has been focused on the application of dangerous chemical such as 5-bromo-3-sec-butyl-6-methyluracil (Hyvar-X), xylophene, aldrin, malathion, parathion, DDT (Dichloro Diphenyl Trichloroethane) and CCA (Chromate Copper Arsenate). The chemical could be substituted by natural compound in the form of essential oil, taken from lemongrass, clove, nutmeg, and ginger, because they have active substances such as citronellal, citronellol, geraniol, eugenol, cineol and camphene that could exterminate, kill, and remove insect, bacteria, and fungi. The application of essential oil as conservation material is safe for the environment and human. Moreover, it could control damages in a cultural heritage.
\end{abstract}

Kata Kunci : Essential oil, Active substance, Conservation material

\section{Pendahuluan}

Indonesia mempunyai banyak benda cagar budaya warisan dari nenek moyang yang tidak ternilai harganya. Beberapa benda cagar budaya telah masuk dalam warisan dunia UNESCO seperti Candi Borobudur, Candi Prambanan, batik, dan wayang. Benda cagar budaya terbuat dari batu, kayu, kertas, dan kain. Benda cagar budaya harus dilindungi dari kepunahan dan kerusakan akibat proses alam seperti hujan asam, serangan serangga, jamur, cendawan, dan mikroba. Jenis mikroba yang banyak tumbuh di batuan yaitu fungi, jamur, dan alga. Mikroba tersebut mudah berkembang pada batuan, batu pasir, granit, batu kapur, dan gypsum (Burford et al., 2003). Pertumbuhan mikroba pada batuan tergantung pada faktor lingkungan seperti ketersediaan air, $\mathrm{pH}$, iklim, sumber nutrisi, komposisi batuan, porositas, dan permeabilitas batuan.

Beberapa penelitian telah dilakukan untuk melindungi bangunan bersejarah dari kerusakan dan pelapukan (Leisen et al. 2004; Triyana dan Soesilo 2013; Singh 2004; Gupta et al. 2012). Selama ini upaya konservasi masih menggunakan pestisida, fungisida, dan insektisida sintetik seperti 5-bromo-3-sec-butyl-6-methyluracil (Hyvar-X), xylophene, aldrin, malathion, parathion, DDT (Dichloro Diphenyl Trichloroethane), dan CCA (Chromated Copper Arsenat) (Winkler 1994; Sing 2004; Gupta et al. 2012). Bahan-bahan tersebut merupakan bahan berbahaya dan beracun, yang menyebabkan bahaya bagi manusia yang melakukan konservasi, pengunjung, dan lingkungan sekitar benda cagar budaya. Bahan-bahan tersebut dapat menyebabkan kanker karena bersifat karsinogenik dan mutagenic sehingga dilarang digunakan untuk konservasi BCB. Oleh karena itu, penting untuk mencari bahan konservan alternatif yang aman dan ramah lingkungan.

Indonesia mempunyai keanekaragaman hayati tanaman penghasil minyak atsiri seperti sereh dapur minyak cengkeh (Eugenia aromatica), minyak sereh wangi (Andropogon nardus) dan minyak kayu manis (Cinnamomum 
spp.), yang mengandung senyawa pestisida berbasis minyak atsiri telah lolos registrasi dari EPA (Environmental Protection Agency) dan dinyatakan aman dari GRAS (Generally Recognized as Safe) (Koul et al., 2008) sehingga ramah terhadap manusia dan lingkungan. Penelitian penggunaan minyak atsiri untuk pestisida, fungisida, dan insektisida telah banyak dilakukan umumnya untuk melindungi tanaman, benzene dan gugus $\mathrm{OH}$, sehingga dapat berperan sebagai pestisida nabati. Sereh dapur dan sereh wangi dapat digunakan sebagai penolak serangga hama dan juga nyamuk (Zanellato et al. 2009).

Untuk memperoleh informasi lebih lengkap tentang jenis minyak atsiri sebagai konservan alami maka pada makalah ini dikemukakan jenis-jenis minyak atsiri, cara isolasi, dan analisis serta, aktivitasnya yang didasarkan pada berbagai sumber literatur.

\section{Tinjauan Pustaka}

\section{Proses Pelapukan Batu Candi Borobudur}

Salah satu sebab kerusakan benda cagar budaya adalah pelapukan oleh bahan-bahan organik. Pelapukan organik yaitu proses penghancuran benda cagar budaya yang diakibatkan oleh aktivitas makhuk hidup, baik hewan maupun tumbuhan. Beberapa organisme penyebab pelapukan yaitu bakteri dan jamur. Bakteri merupakan salah satu jasad renik yang berbentuk seperti batang, peluru, dan sekrup. Bakteri termasuk makhluk hidup yang kasat mata. Untuk dapat mengamati dan mengenal bakteri secara seksama diperlukan mikroskop. Selain bakteri, organisme penyebab kerusakan yang lain adalah jamur. Jamur dapat juga disebut fungi atau cendawan. Jamur merupakan organisme yang tidak mempunyai klorofil atau bersifat heterotrof. Untuk mempertahankan dirinya, jamur hidup sebagai parasit dan saprofit. Jamur tidak mempunyai akar, batang, dan daun, sehingga disebut tumbuhan thalus. Jamur berkembang biak secara kawin dan tidak kawin. Perkembangbiakan secara kawin dilakukan dengan cara konjugasi, askospora, dan basidiospora. Perkembangan dengan cara tidak kawin dilakukan dengan membentuk spora, membelah diri, fragmentasi, dan dengan kondium.

Berdasarkan hasil penelitian di Candi Borobudur, bakteri dan jamur dapat mempercepat proses pelapukan. Batuan Candi Borobudur yang kaya mineral penting merupakan tempat yang tepat bagi tumbuhnya organisme saprofit. Mineral-mineral batuan tersebut bereaksi dengan bahan-bahan organik dan makhluk hidup saprofit sehingga terjadilah pelapukan. Mikroorganisme penyebab kerusakan yang ditemukan di Candi Borobudur di antaranya adalah bakteri, alga, dan jamur. Bakteri yang tumbuh di Candi Borobudur di antaranya adalah bakteri fotoautotrof yang dapat mensintesis senyawa organik dengan menggunakan energi cahaya matahari tidak langsung. Bakteri tersebut menghasilkan berbagai senyawa asam yang dapat bereaksi dengan oksida batuan. Contoh bakteri yang ada pada batuan Candi Borobudur adalah Amonifiri, SP., Aceutobacteur dan Fictobacteur fixing.

Alga juga ditemukan di batuan Candi Borobudur. Alga yang dapat hidup di Candi Borobudur atau batuan disebut Perifiton dari kelas Cyanophyceae (alga biru) dan Chlorophyceae (Alga hijau). Alga biru merupakan vegetasi perintis, yaitu merupakan tumbuhan yang mampu menghancurkan batuan sehingga dapat hidup di daerah tersebut. Alga dapat berfotosintesis dan mampu hidup pada lingkungan dengan suhu $80 \mathrm{C}$, sehingga dapat bertahan lama pada batuan Candi Borobudur. Spesies alga yang ditemukan di Candi Borobudur adalah Nostoceae, Gleocapsa, dan Chlorophyceae bersel satu.

Fungi (jamur) merupakan organisme bersifat saprofit pada Candi Borobudur. Jamur memperoleh makanan secara tidak langsung dari makhluk hidup. Celah-celah Candi Borobudur yang lembab, kurang cahaya matahari, dan banyak mengandung zat-zat organik, merupakan daerah yang paling tepat bagi pertumbuhan jamur. Beberapa jamur yang tumbuh pada

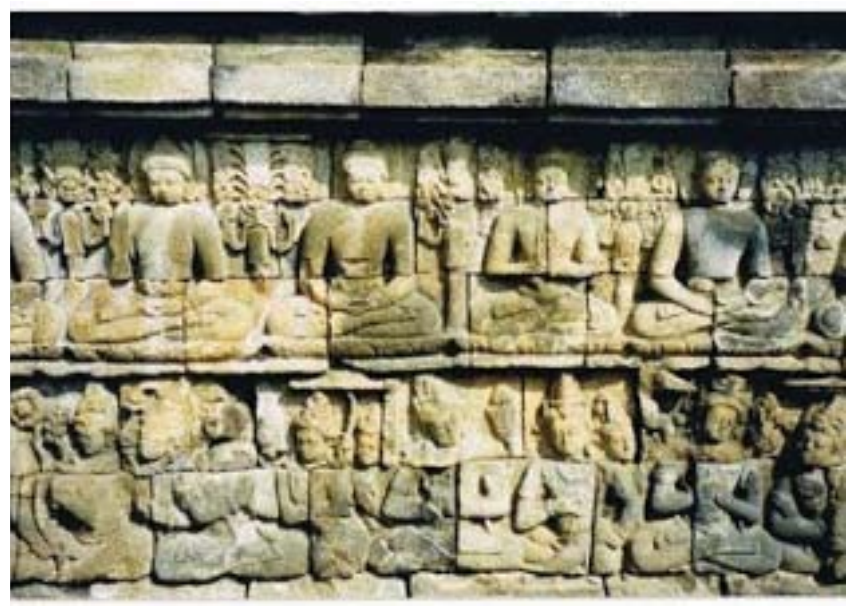

Gambar 1. Cagar budaya berbahan batu yang ditumbuhi oleh mikroba jenis jamur dan alga 
batuan Candi Borobudur seperti aspergilus nigeruan tioghom, aspergilus tlavus link, dan rhyzopus orrhyzus ficher. Gambar 1 menunjukkan mikroba yang tumbuh di berbagai benda cagar budaya.

\section{Minyak Atsiri}

Minyak atsiri adalah minyak yang diperoleh dengan cara destilasi, ekstraksi, dan enfluorasi dari bagian tanaman: akar, batang, kulit, daun, bunga, dan buah. Contoh tanaman penghasil minyak atsiri dapat dilihat pada Tabel. 1. Minyak atsiri yang dengan mudah dapat dipisahkan menjadi komponenkomponennya (dapat secara kimia atau fisika) yang dapat merupakan bahan dasar untuk dikonversi menjadi produk-produk lain seperti minyak sereh, minyak daun cengkeh, minyak permen, dan minyak terpentin. Minyak atsiri yang sukar dipisahkan menjadi komponen-komponennya dan digunakan secara langsung seperti minyak nilam, minyak kenanga, dan minyak akar wangi.

\section{1 Teknik Isolasi Minyak Atsiri}

Minyak atsiri dapat didestilasi dari bagian tanaman seperti daun, batang, akar, buah, kulit batang, dan bunga. Berbagai jenis teknik isolasi minyak atsiri seperti destilasi kukus, destilasi rebus, destilasi uap air, ekstraksi, dan enfluorasi. Berbagai jenis destilasi ditunjukkan pada Gambar 2. Destilasi kukus (Gambar 2A) sangat sesuai untuk isolasi minyak atsiri sereh, kenanga, dan cengkeh. Destilasi rebus sangat sesuai untuk isolasi minyak atsiri empon-empon seperti jahe, kencur, kunyit, temu mangga, dan lain-lain. Teknik dengan destilasi rebus (Gambar 2B), bahan baku harus dihancurkan sampai halus dan dicampur dengan air menggunakan perbandingan yang sesuai. Teknik ini memerlukan api yang kecil supaya sampel tidak hangus. Teknik yang banyak digunakan untuk isolasi minyak atsiri berbahan baku keras sepeti daun, batang, dan akar yaitu destilasi uap air (Gambar 2C). Keberhasilan teknik ini sangat ditentukan dengan tekanan uap yang dihasilkan oleh boiler. Untuk optimasi hasil biasanya bahan baku perlu dikeringkan untuk mengurangi kandungan air dan dihaluskan untuk mengeluarkan semua minyak atsiri dalam jaringan tanaman.
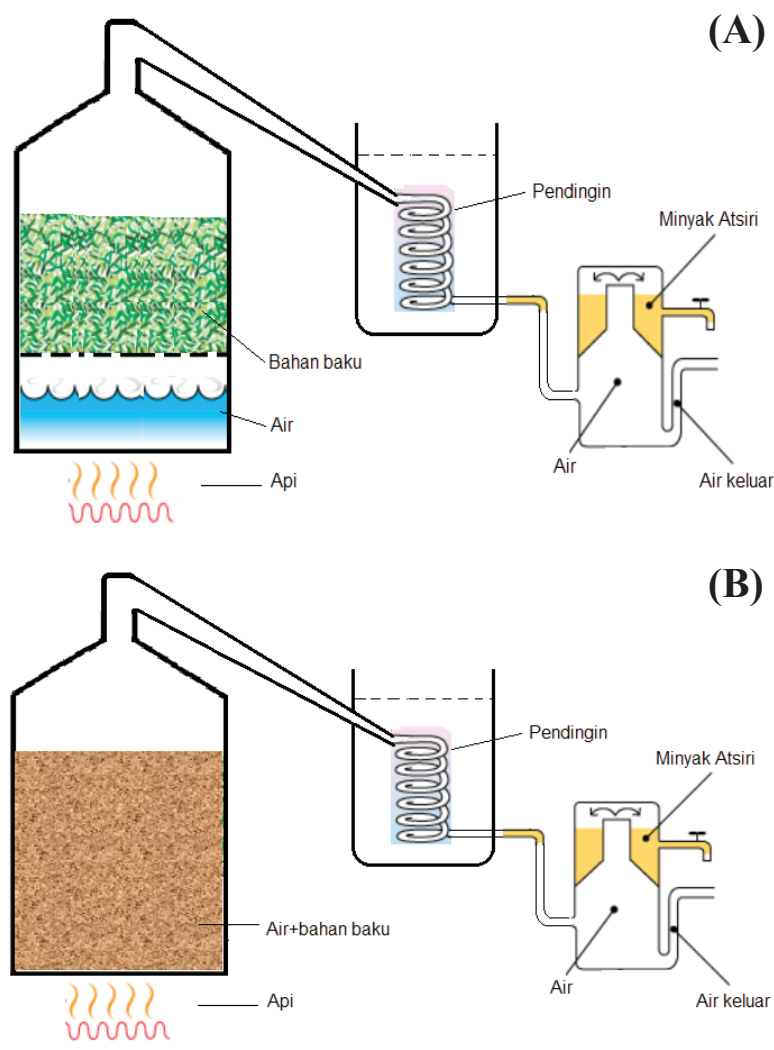

Tabel 1. Tanaman penghasil minyak atsiri yang sudah umum dibudidayakan

\begin{tabular}{|c|c|c|c|c|}
\hline No. & Tanaman & Bagian tanaman & Minyak atsiri & Komponen utama \\
\hline 1. & Pohon cengkeh & Bunga/daun & Cengkeh & Eugenol \\
\hline 2. & Pohon lawang & Kulit & Lawang & Eugenol dan safrol \\
\hline 3. & Pohon pinus & Kulit/batang/getah & Terpentin & Alfa-pinen \\
\hline 4. & Pohon cendana & Kulit batang/akar & Cendana & Santanol \\
\hline 5. & Pohon kayu putih & Daun & Kayu putih & Sineol \\
\hline 6. & Pohon kenanga & Bunga & Kenanga & Ester \\
\hline 7. & Pohon kayu manis & Kulit/batang & Kayu manis & Sinamil aldehida \\
\hline 8. & Sereh & Daun & Sereh & Sitronelal, sitronelol \\
\hline 9. & Nilam & Daun & Nilam & Patchouli alkohol \\
\hline 10. & Menthaarvensis & Daun & Permen & Mentol \\
\hline 11. & Akar wangi & Akar & Akar wangi & Vetiverol \\
\hline 12. & Adas & Biji & Adas & Anetol, estragol, fenson \\
\hline 13. & Gondopuro & Daun & Gondopuro & Metil salisilat \\
\hline
\end{tabular}




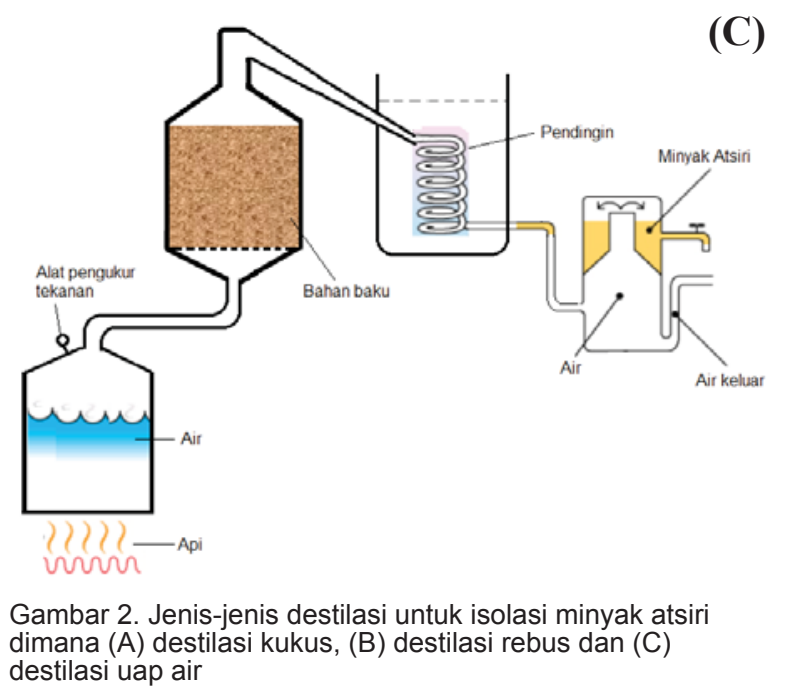

\subsection{Analisis Komponen Senyawa Aktif dalam}

\section{Minyak Atsiri}

Analisis komponen senyawa aktif dalam minyak atsiri dapat dilakukan dengan menggunakan alat kromatografi gas spektrometri masa atau GC-MS. Salah satu contoh hasil analisis minyak atsiri jahe yang dihasilkan dari destilasi rebus dengan perbandingan air dan jahe (1:1). Kromatogram minyak atsiri jahe dapat dilihat pada Gambar 3.

Komponen senyawa aktif dalam minyak atsiri jahe mengandung lebih dari 25 senyawa. Nama-nama senyawa aktif hasil analisis dengan kromatografi dapat diketahui dengan menggunakan spektrometri masa ditunjukkan pada Tabel 2 .

Pada Gambar 4 terlihat bahwa minyak atsiri daun cengkeh mengandung lima senyawa aktif yaitu eugenol $76,86 \%$, beta carryophylllene $18,90 \%$, alpha humulene $2,53 \%$, alpha copaene $1,03 \%$ dan delta cadinene $0,67 \%$.

\section{Aktivitas Minyak Atsiri sebagai Antibakteri dan}

\section{Antijamur}

Aktivitas biologi minyak atsiri terhadap mikroba telah banyak diteliti terutama terhadap bakteri patogen pada manusia dan hewan. Hasil beberapa penelitian menunjukkan bahwa sejumlah minyak atsiri mempunyai aktivitas terhadap bakteri patogen baik yang bersifat gram negatif maupun positif dengan nilai MIC (Minimum Inbibitory Concentration) yang bervariasi. Sejumlah minyak atsiri juga dilaporkan mempunyai aktivitas terhadap bakteri pathogen pada tanaman (Hartati et al., 1994; Supriadi et al., 2008; Pradhanang et al., 2003; Vasinauskiene et al.,2006; Kotan et al., 2007).

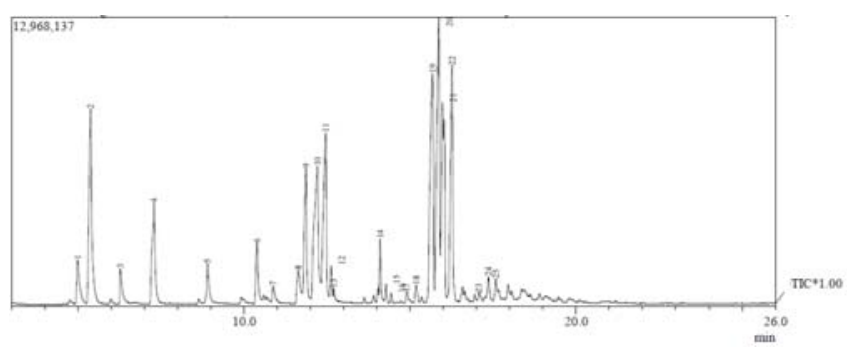

Gambar 3. Kromatogram minyak atsiri jahe hasil destilasi rebus Tabel 2. Komponen senyawa aktif dalam minyak atsiri

\begin{tabular}{|clc|}
\hline No. & \multicolumn{1}{c}{ Nama Senyawa Kimia } & Kadar (\%) \\
\hline 1. & a-pinene & 3,57 \\
\hline 2. & Camphene & 12,47 \\
\hline 3. & b-pinene & 0,23 \\
\hline 4. & 1,8-cineole & 17,89 \\
\hline 5. & Linalool & 0,23 \\
\hline 6. & Borneol & 3,10 \\
\hline 7. & a-terpineol & 1,15 \\
\hline 8. & Nerol & 0,23 \\
\hline 9. & Neral & 0,21 \\
\hline 10. & Bisabolene & 1,63 \\
\hline 11. & Zingiberene & 0,32 \\
\hline
\end{tabular}

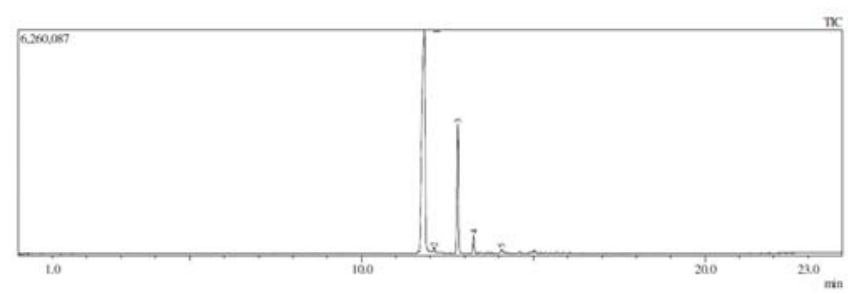

Gambar 4. Kromatogram minyak atsiri daun cengkeh hasil destilasi uap air

Hasil beberapa penelitian menunjukkan bahwa sejumlah minyak atsiri juga mempunyai aktivitas terhadap jamur. Aktivitas antijamur yang dimiliki oleh minyak atsiri juga berhubungan dengan senyawa monoterpenik fenol khususnya timol, karvakrol, dan eugenol (Isman, 2000).

\section{Aktivitas Minyak Atsiri sebagai Antivirus, Antinematoda, dan Antigulma}

Sejumlah minyak atsiri juga dilaporkan dapat menghambat infeksi dari virus (Koul et al., 2008; Reichling, 2009). Hasil penelitian menunjukkan bahwa minyak atsiri juga efektif terhadap virus 
pathogen pada tanaman seperti TMV, CPMV, BCMV, MBMV, SBMV, CaVMV (Bishop, 1995; Reitz et al., 2008). Menurut Mustika et al. (1994), Sangwan et al. (1990), dan Tariq (2010), sejumlah minyak atsiri dan komponennya seperti eugenol mempunyai aktivitas terhadap nematoda parasit tanaman.

Selain aktivitasnya terhadap mikroba sejumlah minyak atsiri juga berpotensi untuk digunakan sebagai herbisida (Batish et al., 2008; Isman, 2000, Zanellato et al., 2009). Menurut Batish et al. (2008), minyak Eucalyptus dapat mengendalikan gulma yang sifatnya species spesifik. Minyak cinamon dan pepermin dilaporkan dapat menghambat perkecambahan biji beberapa jenis gulma di daerah Mediterania. Sementara minyak lavender juga berpotensi sebagai antigulma karena dapat menghambat pertumbuhan gulma Vicia faba dan mikroba pengganggu tanaman (Zanellato et. al., 2009).

\section{Aktivitas Minyak Atsiri sebagai Antivirus, Antinematoda, dan Antigulma}

Menurut Dubey et al. (2008), Dubey et al. (2010), Isman (2000), dan Koul et al. (2008), aktivitas biologi minyak atsiri terhadap serangga dapat bersifat menolak (repellent), menarik (attractant), racun kontak (toxic), racun pernafasan (fumigant), mengurangi nafsu makan (antifeedant), menghambat peletakan telur (oviposition deterrent), menghambat petumbuhan, menurunkan fertilitas, serta sebagai antiserangga vektor. Hasil dari beberapa penelitian yang telah dilakukan tersebut di atas menunjukkan bahwa sejumlah minyak atsiri mempunyai aktivitas biologi yang berspektrum sangat luas baik terhadap mikroba (bakteri, jamur, virus, nematoda) maupun terhadap serangga hama dan vektor patogen yang hidup di sekitar rumah serta serangga hama tanaman.

\section{PEMBAHASAN}

\section{Minyak Atsiri Cengkeh dan Sereh untuk Bahan}

\section{Konservasi Bangunan Cagar Budaya}

Potensi minyak atsiri sebagai pestisida nabati juga sangat besar ditinjau dari aktivitas biologi, efikasi, kompatibilitas, organisme sasaran, serta keamanannya terhadap lingkungan dan kesehatan manusia. Sebagai contoh komponen kimia minyak sereh wangi adalah sitronellal dan garaniol. Kedua komponen tersebut menentukan intensitas bau, harum, serta nilai harga minyak sereh wangi. Kadar komponen kimia penyusun utama minyak sereh wangi tidak tetap dan tergantung pada beberapa faktor. Komposisi minyak sereh wangi dapat terdiri dari beberapa komponen, ada yang mempunyai 30-40 komponen, yang isinya antara lain alkohol, hidrokarbon, ester, alaehid, keton, oxida, lactone, terpene, dan sebagainya.

Beberapa jenis minyak atsiri mengandung senyawa monoterpen yang mempunyai sifat anti mikroba seperti cymene, sabinen, alpha pinen, betapinen, sitronellol, geraniol, carvacrol, thymol, farnesol, dan caryophyllene. Struktur dan gugus fungsi yang berperan sebagai antibakteri ditunjukkan pada Gambar 5 dan 6 .

Penelitian yang telah dilakukan oleh Zanellato et al. (2009) komposisi kimia minyak atsiri bunga cengkeh dari Turki melalui proses penyulingan uap mendapatkan komponen terbesar adalah 87\% eugenol,

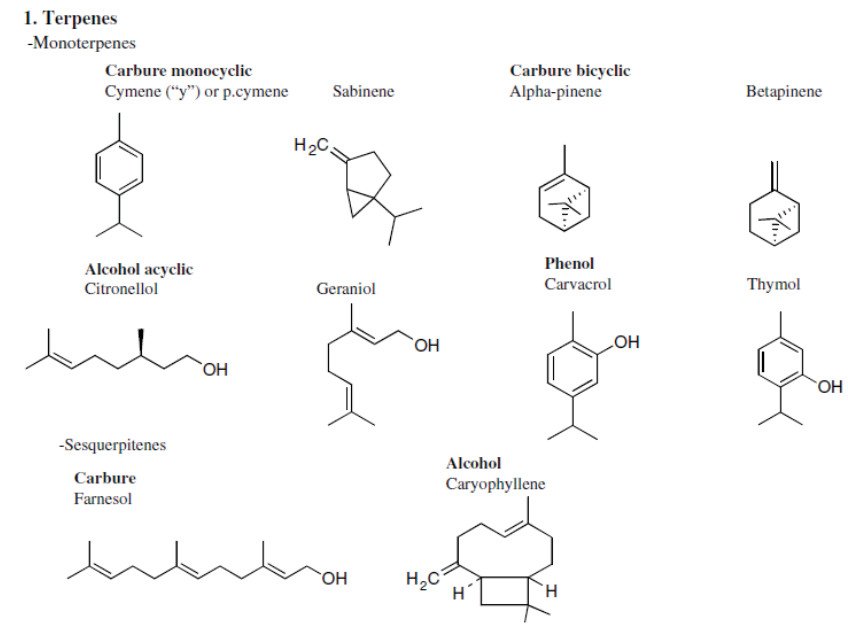

Gambar 5. Contoh senyawa monoterpen dan sesqueterpen dalam minyak atsiri yang mempunyai peran sebagai antibakteri (Oyen and Dung, 1999).

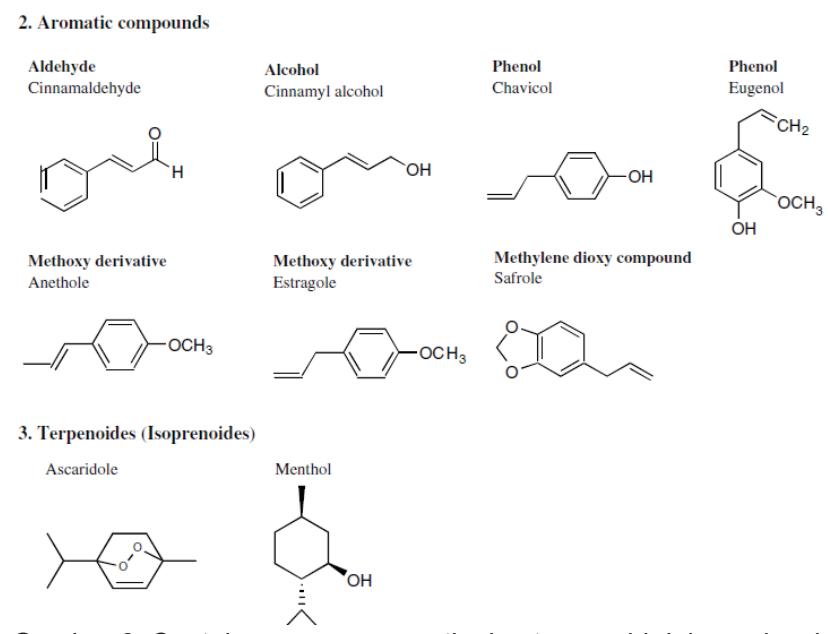

Gambar 6. Contoh senyawa aromatic dan terpenoid dalam minyak atsiri yang mempunyai peran sebagai antibakteri (Oyen and Dung, 1999). 
8,01\% eugenyl asetat dan 3,56\% $\quad \beta$-caryophyllene. Sangwan et al. (1990) menganalisa komposisi kimia dalam minyak daun cengkeh menggunakan GC-MS didapat 23 komposisi kimia dengan kadar komponen terbesar adalah eugenol (76,8\%), $\quad \beta$-caryophyllene $(17,4 \%)$, R-humulene (2,1\%), dan eugenylacetate (1,2 $\%)$.

Beberapa jenis pestisida berbasis minyak atsiri telah diproduksi dan sering digunakan untuk mengendalikan patogen, serangga hama, dan vector patogen di lingkungan rumah, rumah kaca, dan peternakan. Pestisida berbasis minyak atsiri juga mempunyai nilai MIC (Minimum Inhibitory Concentration) dan LD (Lethal Dose) yang rendah, kompatibel, dan menghasilkan produk pertanian yang bebas residu (Hartati, 2012).

Berdasarkan beberapa penelitian di atas menunjukkan bahwa minyak atsiri mengandung senyawa

\section{Daftar Pustaka}

Batish, D. R., H. P. Singh, and R. K. Kohli. 2008. Eucalyptus essential oil as a natural pesticide. Forest Ecology and Management 256: 2166-2174.

Burford, P.E., Kierans, M., Gadd, M.G. 2003, Geomycology: fungi in mineral substrata, Mycologyst 17: 98-107.

Dubey, N. K. , B. Srivastava, and A. Kumar. 2008. Current status of plant products as botanical pesticides in storage pest management. J. of Biopesticides 1 (2):182-186.

Dubey, N. K., R. Shukla, A. Kumar, P. Singh, and B. Prakash. 2010. Prospects of botanical pesticides in sustainable agriculure. Current Science, 4 (25): 479480.

Gupta, S.P., Sharma, K., and Chhabra, B.S., 2012, Biodeterioration and Chemical Conservation, Journal of Conservation Science in Cultural Heritage, Vol. 12: 135-147.

Hartati, S. Y., E. M. Adhi, A. Asman, dan Nuri Karyani. 1994. Efikasi minyak cengkeh terhadap bakteri Pseudomonas solanacearum. Prosiding Seminar Hasil Penelitian dalam Rangka Pemanfaatan Pestisida Nabati, Bogor. Badan Penelitian dan Pengembangan Pertanian. Balittro. Bogor. Hlm. $37-42$.

Hartati, S.R., 2012, Prospek Pengembangan Minyak Atsiri Sebagai Pestisida Nabati (Prospect Of Essential Oils kimia yang berpotensi untuk membunuh bakteri, lumut, jamur, dan mikroorganisme, sehingga dapat digunakan sebagai bahan konservan BCB berbahan batu, kayu, atau kertas. Oleh karena itu disarankan untuk dilakukan penelitian pada BCB secara langsung.

\section{Kesimpulan}

Minyak atsiri dapat diperoleh dari tanaman cengkeh, sereh, jahe, nilam dan lain-lain. Pada umumnya mengandung zat aktif yaitu eugenol, sitronelal, sitronelol, geraniol, sineol, kamphen dan pachuoli alcohol. Zat-zat tersebut berpotensi untuk membunuh bakteri, lumut, jamur dan mikroorganisme, sehingga berpotensi sebagai bahan koservan batu, kayu, atau kertas, yang disarankan untuk diuji di lapangan pada BCB.

Developed As Botanical Pesticides), Perspektif, 11 (1): $45-58$.

Isman, M. B. 2000. Plant essential oils for pest and disease management. Crop Protection. 19: 603-608.

Koul, O., S. Walia, and G. S. Dhaliwal. 2008. Essential oils as green pesticides: Potential and constrains. Biopesticides. Int. 4 (1): 63-84.

Kotan, R., F. Dadasoglu, S. Kordali, A. Cakir, N. Dikbas, and R. Cakmakci. 2007. Antibacterial activity of essential oils extracted from some medicinal plants, carvacrol, and thymol on Xanthomonas axonopodis pv. vesicatoria (Doidge) dye causes bacterial spot disease on pepper and tomato. J. of Agricultural Technology 3 (2): 299-306.

Koul, O., S. Walia, and G. S. Dhaliwal. 2008. Essential oils as green pesticides: Potential and constrains. Biopesticides. Int. 4 (1): 63-84.

Leisen, H., Plehwe, L.E., and Warrack, S., 2004, Success and limits for stone repair mortars based on tetra ethyl silicate-conservation of the reliefs at Angkor Wat Temple, Cambodia. In Proc. of the 10th internet. Congr. On Deterioration and Conservation of Stone, Stockholm 7 June-2 July, Stockholm.

Mustika, I. , dan A. Rahmat. 1994. Efikasi beberapa macam produk cengkeh terhadap nematoda lada. Prosiding 
Seminar Hasil Penelitian dalam Rangka Pemanfaatan Pestisida Nabati, Bogor. Badan Penelitian dan Pengembangan Pertanian. Balittro. Hlm. 49-55.

Oyen, L.P.A and Dung, N.X., 1999, PROSEA (Plant Resource of South-East Asia) No. 19 Essential-Oil Plants. Backhuys Publisher, Leiden Netherlands. Pradhanang, P. M., M. T. Momol, S. M. Olson, and J. B. Jones. 2003. Effects of plant essential oils on Ralstonia solanacearum population density and bacterial wilt incidence in tomato. Plant Disease 87:423-427.

Reichling, J., P. Schnitzler, U. Suschke, and R. Saller. 2009. Essential oils of aromatic plants with antibacterial, antifungal, antiviral, and citotoxic properties-an overview. Forsch Komplementmed. 16: 79-90.

Reitz, S. R. G. Maiorino, S. Olson, R. Sprenkel, A. Crescenzi, and M. T. Momol. 2008. Interesting plant essential oils and kaolin for the sustainable management of thrips and tomato spotted wilt on tomato. Plant Disease. 92: 878-886.

Sangwan, N. K., B. S. Verma, K. K. Verma, and K. S. Dhindsa. 1990. Nematicidal activity of some essential plant oils. Pestic. Sci. 28: 331-335.

Singh, G.M., 2004, Chemical Conservation of Monuments, Abhilekha, Vol 15: 132-139.

Supriadi, S. H. Hartati, Makmun, N. Karyani. 2008. Aktivitas biologi minyak atsiri cengkeh-kayumanis terhadap Ralstonia solanacearum pada jahe. Prosiding Seminar Nasional engendalian Terpadu Organisme Pengganggu Tanaman Jahe dan Nilam. Bogor. Hlm: $55-60$
Tariq, R.M., Naqvi, S.N.H. Choudhary, M. I. and A. Abbas. 2010. Importance and Implementation of essential oil of Pakistanian Acorus calamus Linn., as a biopesticide. Pakistanian J. Bot. 42 (3): 2043-2050.

Triyono, K., dan Soesilo, H., 2012, Metode Konservasi Benda Cagar Budaya Berbasis Elektro-osmosis, Balai Konservasi Borobudur, Jawa Tengah, Indonesia.

Vasinauskiene, M., J. Radusiene, I. Zitikaite, and E. Surviliene. 2006. Atibacterial activities of essential oils from aromatic and medicinal plants against growth of phytopathogenic bacteria. Agronomy Research 4 (Special issue): 437-440.

Winkler, E.M., 1994, Stone in Architecture: Properties, Durability with 63 Tables, Springer Science \& Business Media, New York, USA.

Zanellato, M., E. Masciarelli, L. Cassori, P. Boccia, E. Sturcio, M. Pezzella, A. Cavalieri, and F. Caporali. 2009. The essential oils in agriculture as an alternative strategy to herbicides: a case study. International J. of Environ. and Health. 3: 198-212. 